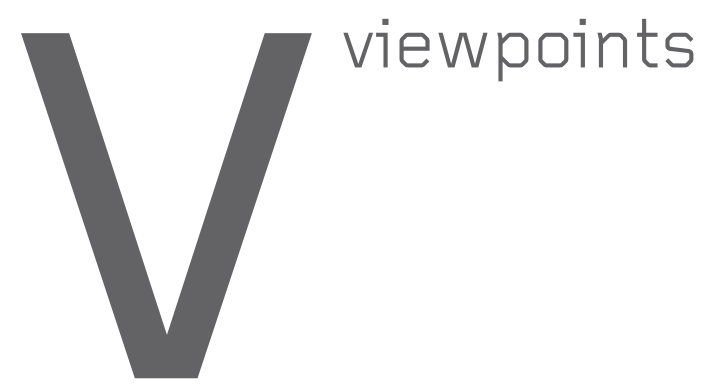

\title{
Emerging Markets Corporate Social Responsibility and Global IT Outsourcing
}

How to improve IT outsourcing relationships while doing good for society.

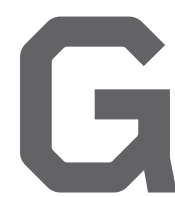

LOBAL IT OUTSOURCING (GITO) is an increasingly accepted business tactic, and continues to grow at healthy rates. In 2008, the value of the global ITO market was estimated at between $\$ 220$ to $\$ 250$ billion. The estimate for 2009-2014 is that ITO will grow by $6 \%-9 \%$ per annum. ${ }^{8}$

Today, corporate social responsibility (CSR) is a priority item on the agenda of almost every business organization. Not surprisingly, leading GITO providers have embraced it, and ongoing research at the University of Manchester suggests that some buyers and providers of GITO are gaining competitive advantage from the implementation of CSR projects. ${ }^{1,3}$

Elkington ${ }^{4}$ describes how CSR can be integrated into every aspect of social, political, and economic activity, creating "win-win-win strategies...to simultaneously benefit the company, its customers, and the environment." Elkington describes the "triple bottom line" where people, planet, and profits are all considerations in evaluating company performance. He suggests that "successful companies will have little option but to get involved in this rapidly emerging area." Emerson ${ }^{5}$ similarly describes "a significant rise in the number of mainstream corporate CEOs discussing the social and environmental performance of their firms." He concludes that "life is not driven strictly by either social or financial realities...we may use financial resources to expand and sustain the core value of organization, community, and individual."

GITO buyers increasingly expect providers to deliver CSR capability as both parties react to global standards and employee expectations. Most major GITO providers (including the major Indian providers) have therefore striven to meet emerging global CSR standards and many have produced elaborate CSR documents that can be downloaded from their Web sites.

From our research we found that GITO CSR projects can be divided into three categories:

\section{Buyers and providers who collaborate on CSR initiatives create strong business value in the outsourcing relationship and create social value for the communities in which they operate.}

- Philanthropy and good citizenship, for example, making donations to worthy causes, such as the work of the Indian IT outsourcing firm Infosys' Foundation;

- Compliance with standards such as the Global Reporting Initiative (GRI), which is increasingly a standard requirement in outsourcing requests for proposal; and

- Collaborative CSR activity where the outsourcing buyer and provider work together to achieve shared societal goals and also strengthen their relationship, thus "doing well by doing good." Most leading GITO providers participate in the first two CSR categories: they make contributions to good causes and comply with global CSR standards. A few providers and buyers are engaging in collaborative CSR activity and are able to report some interesting benefits.

The third category is relatively new to GITO relationships, and our research has found within it some novel developments. Porter and Kramer refer to this type of CSR activity as "strategic CSR," since companies attain "greater competitiveness through corporate strategy by advancing social conditions." ${ }^{7}$ In our research we found that buyers and providers who collaborate on CSR initiatives create strong business value in the outsourcing relationship, and create social value for the communities in which they operate. Porter and Kramer refer to this as "creating shared value" ${ }^{6}$ through strategic CSR. 


\section{Collaborative CSR in GITO}

GITO providers and buyers who gain advantage from collaborative CSR are proactive in embracing CSR projects that will enhance their existing services or even create new capabilities in their portfolio. One particular example is a joint project by U.K.-based Cooperative Financial Services (CFS) and Steria, a French GITO provider with centers in the U.K. and India. CFS and Steria have collaborated on several CSR projects. A CFS executive told us that as a GITO client they expect of their outsourcing relationships a "common set of values, to build trust with like-minded organizations where we share something in common." This has been realized in the relationship with Steria.

Working together, CFS and Steria support a number of schools in India through the provision of library equipment, computers, sporting equipment, and other funded services to allow students in poor communities to be educated in a wellequipped school. Executives from both companies visit the schools regularly and meet with the teachers, students, and administrators. The local Steria staff visit and work at the schools, mentoring children and contributing budgeted time to the teaching and maintenance of the school project equipment. In parallel, Steria and CFS staff collaborate on social projects in the U.K., contributing staff time jointly to supporting local projects such as community shelters and schools. This is one example of what could be done collaboratively but it is not unique or exclusive; Steria has implemented similar collaborative CSR models with other clients besides CFS.

Overall, collaboration on CSR projects has built a greater level of trust and mutual understanding between CFS and Steria. This enhanced trust and understanding creates work force-related benefits. It contributes to reduced attrition, improves staff retention, and improves productivity through improved team morale.

Collaborative CSR benefits all parties: the buyer gains a more productive provider; the provider gains a more loyal and effective work force; society gains a better-equipped school with students who are more likely succeed

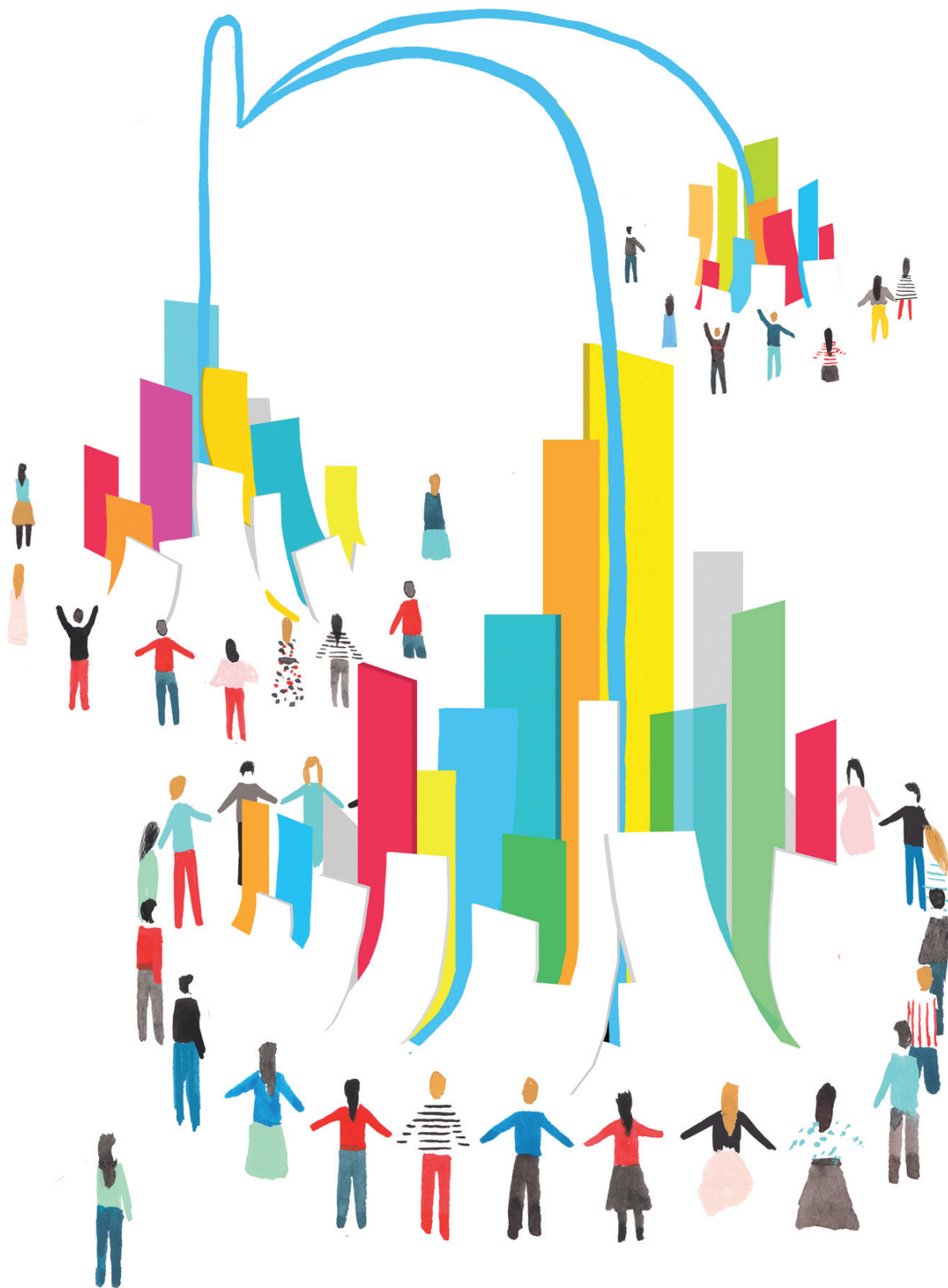

in life, and who may one day find employment in the GITO industry. This fits with the Porter and Kramer definition of shared value from strategic CSR.

Steria staff told us attrition rates on the CFS project team in Steria India were substantially lower than attrition rates on similar project teams. This results in reduced costs for recruitment, training, and knowledge transfer. A CFS executive stated: "India is booming again this year. And attrition is a massive issue for the industry... attrition on the CFS account is really nothing compared to others, I mean it stands out."..."it is certainly linked to the strength of the relationship between the two organizations which is really visible to the guys in India."

Collaborative CSR helps inspire commitment to stay, work longer and harder for a responsible and caring organization. The willingness to collaborate demonstrates the importance of CSR values evidenced through personal contributions. The payback is in the form of improved productivity and reduced retraining costs. Retained staff tends to be more productive than those newly employed. For the buyer and provider this commitment offers the ability to work through difficult and unexpected problems in the outsourcing relationship. A CFS executive told us: "When you are under pressure of getting the tests done against a tight deadline, do you know what the guys say? Well, time to go home now or do they stay for midnight? These guys stay until midnight and beyond and all 
night if necessary....the school [CSR] thing is just a little part of that-it just builds that."

Similarly, this was mirrored by the provider: "People stay longer, sometimes they're investing a lot of their time and it's not paid, I won't necessarily see it on my bottom line, but you will see it on the productivity of that project, of hitting targets, etc."

For the outsource provider and buyer, the enhanced trust improves organizational and individual interpersonal communications. CFS managers told us that joint CSR agendas can be another tool in building effective communications and business relationships. As one CFS executive explained: "I would just say it massively helps with our relationship and how we work together, and what it does when you're working with people painting a classroom or clearing a play area, you also bring in teamwork and there's so many other things that come into it, other skills, communication. You really get to know the people who you're working with, and when you see them out of a techie environment, it makes a huge difference."

Social networks established outside of the formal work environment on CSR projects tended to lead to esteem between individuals and friendly relationships. Subsequently, staff from both buyer and provider organizations felt able to cut through the formal organizational communications hierarchy to solve problems rather than resorting to formal contractual resolution. A Steria executive echoed a similar sentiment: "So when you've been to these places and shared the experience with people, it does help form a very close relationship...Let's face it, in outsourcing things don't go perfectly well over time, they don't and that's the real-

Opportunities for buyers to work cooperatively with providers on CSR initiatives will grow. ity of it. You're in a world where you're delivering projects and services. It's a fast-moving world and not all projects go perfectly well. Good relationships get you through those situations...you keep the clients that you have, and that's about strong relationships."

\section{Directions on CSR for GITO Buyers and Providers}

What lessons does our research provide for buyers and providers of outsourcing services? We have three suggestions.

- More providers should explore the collaborative CSR option, and seek to match CSR projects with buyers in order to build trust and commitment, reduce attrition, improve productivity, and increase organizational and interpersonal communications. In addition to shared views on CSR, buyers should expect CSR leadership from their outsourcing providers.

- Buyers will increasingly demand evidence of compliance with global CSR standards such as the GRI and the UN Global Compact. In a review of outsource provider public profiles we found that the large global providers demonstrated mature CSR capabilities in terms of meeting global standards, while the mid-tier or smaller outsourcer providers are still building their CSR capability. ${ }^{2}$ We also found that buyers infrequently validate the provider CSR claims. So a caution to outsource buyers: beware of unsubstantiated CSR claims, particularly from small and mid-tier providers. Several independent consultancies are able to assist buyers with CSR audits of potential outsourcing providers.

- Although our case example focused on social responsibility, environmental responsibility is also a component of CSR concern for global IT outsourcing buyers. Providers with data centers and related technologies must be able to demonstrate energy efficiency that exceeds the levels set by buyers and required by governments. For example, a provider should be able to demonstrate reduced carbon emissions through power management that is more efficient than the buyer could achieve. In accordance with environmental responsibility, outsource providers must increasingly comply with government and industry standards.

\section{Conclusion}

In light of the benefits reported in this research, opportunities for buyers to work cooperatively with providers on CSR initiatives will grow. There will be continued uptake of CSR practices by providers, and buyers will need to determine their individual appetite and focus for working collaboratively on such projects.

Finally, we should note that this research is indicative of the reported benefits of collaborative CSR but there are many factors at play. The research has highlighted potentially significant business benefits. However, isolating and quantifying the value of collaborative CSR in substantiated financial terms has not been fully proven. Our research is continuing to examine collaborative CSR at CFS and at other organizations. We welcome comments and contributions from other organizations with similar CSR experiences.

\section{References}

1. Babin, R. and Nicholson, B. Corporate social and environmental responsibility in global IT outsourcing. MIS Quarterly Executive 8, 4 (Dec. 2009), 123-132.

2. Babin, R. and Nicholson, B. How green is my outsourcer: Measuring sustainability in global IT outsourcing. Strategic Outsourcing, International Journal 4, 1 (Jan. 2011), 47-66.

3. Babin, R. and Nicholson B. Sustainability Practices in Global IT Outsourcing. Manchester Business School Research Paper 602, University of Manchester U.K. (June 2010); http://papers.ssrn.com/ abstract $=1683288$

4. Elkington, J. Towards the sustainable corporation: Win-win-win business strategies for sustainable development. California Management Review 36, 2 (Feb. 1994), 90-100

5. Emerson, J. The blended value proposition: Integrating social and financial returns. California Management Review 45, 4 (Apr. 2003), 35-51.

6. Porter, M. and Kramer M. Creating shared value. Harvard Business Review 89, 1/2 (Jan.-Feb. 2011), 62-77.

7. Porter, M. and Kramer M. Strategy and society: The link between competitive advantage and corporate social responsibility. Harvard Business Review 84, 12 (Dec. 2006), 78-92.

8. Willcocks, L.P. and Lacity M. The Practice of Outsourcing: From ITO to BPO and Offshoring. Palgrave, London, 2009.

Ron Babin (rbabin@ryerson.ca) is an assistant professor and associate director at the Ted Rogers School of IT Management at Ryerson University in Toronto and a doctoral candidate at the Manchester Business School, U.K.

Steve Briggs (steve.briggs@cfs.coop) is the head of Strategic Partnerships at Co-operative Financial Services (CFS) in Manchester, U.K., where he has managed severa major outsourcing relationships, and is also a director of the U.K. National Outsourcing Association.

Brian Nicholson (brian.nicholson@manchester.ac.uk) is a senior lecturer at Manchester Business School and has been involved in teaching, research, and consultancy projects in the broad area of global outsourcing of software and other business processes since 1995.

Copyright held by author. 